\title{
MTRR wt Allele
}

National Cancer Institute

\section{Source}

National Cancer Institute. MTRR wt Allele. NCI Thesaurus. Code C105127.

Human MTRR wild-type allele is located in the vicinity of $5 \mathrm{p} 15.31$ and is approximately 55 $\mathrm{kb}$ in length. This allele, which encodes methionine synthase reductase protein, is involved in both B vitamin metabolism and methionine synthesis. Mutation of the gene is associated with both folate-sensitive neural tube defects and methylcobalamin deficiency type $\mathrm{E}$. 